regions which he sought. His colleagues plan to complete and publish this unique and important work as soon as practicable.

In this frequency-range, the absorption of cosmic radio-waves in passing through the ionosphere is often appreciable and the interpretation of cosmic observations requires a knowledge of absorption in the various ionospheric layers. Shain's pioneering work on such absorption, particularly interesting at the time of solar flares, sufficed for his own purposes and has since given rise to a vigorous branch of ionospheric research which follows the inverse approach and uses observations of the absorption of cosmic radio waves to obtain information about phenomena in the ionosphere.

A by-product of the cosmic radio wave studies concerns radio emission from Jupiter. Following the discovery in the United States in 1956 of emission from this planet in the $20-\mathrm{Mc}$./s. range, Shain examined his old records. He found a large number of extended bursts of emission, which had previously been attributed to terrestrial interference, but which could now be identified with reasonable certainty as due to emission from Jupiter. Examination of the times of occurrence of these bursts showed a remarkable correlation with the rotation period of Jupiter, indicating that the emission originated in a very fow active areas on the planet which remained in fixed positions for long periods.

Alex. Shain was a wonderful colleague in the laboratory-imaginative, well balanced, exceedingly unselfish, and a real friend to all. In his home community he was a leader in Church affairs. In murra where he lived he was, among other things, the Anglican Church in the Sydney suburb of TurraSunday school superintendent, lay reader and the leader of a Bible Study Group. He was a man who exemplified the principles of Christianity in all his dealings with men. J. L. Pawsex

\section{Mr. K. J. F. Park}

THE death of Kenneth John Frederick Park in a drowning accident on March 2 at the age of thirty-two has robbed the Nature Conservancy of a most valued officer, science of a first-rate ecologist and the world of a man of rare quality.

Park was educated at the Royal Grammar School, Newcastle upon Tyne, and at King's College, New. castle. Between school and college he served three years in the Royal Air Force, and this took him to the Middle East and gave width of experience to an alert mind. He left the University with a first-class degroe in botany and a good knowledge of the aretic-alpine vegetation of northern England, the Scottish Highlands and the Hebrides. His interest in field botany led him to postgraduate work on the ecology of Upper Teesdale, particularly the sugar-limestone outcrops. This work was interrupted in 1954 by his appointment as officer-in-charge of the Nature Conservancy's Moor House Field Station more than 1,800 ft. above sealevel in the northern Pennines.

His basic scientific interest was the conservation of upland Britain, using the word conservation in a wide and humanitarian sense. His own research was focused on the potential productivity of the grasslands on mineral soils. He aimed to get quantitative data on long-term trends in fertility-levels, as determined by grazing, leaching. soil weathering and other factors causing gain or loss of nutrients. During the past year or two he had been attacking these problems directly, for example by observations on rates of leaching, but before this he had put in much intensive work on recording the existing state of the various grassland types on the Nature Reserve. He did this by setting up a series of sheep exclosures and using various methods of mapping, point-quadrat recording, and detailed photography of vegetation. The methods were not of course original, but the standard of accuraey and the finish of the work are altogether outstanding and are witnessed in the volumes of the Nature Reserve Record Book. The plots have been laid out and recorded as the firm starting-point for observations visualized as going on over a century or more.

Over and above his own research line, he built up an impressive collection of information about the Reserve and the surrounding countryside, and himself contributed many superb photographs.

When he went to the Field Station he had nothing to work on but rather sketchy possibilities ; but in his six years of imaginative and efficient management. he created a live centre of scientific work in remote and difficult conditions, where visiting workers could come and use their time productively. His achievement was due not only to his very hard work and exceptionally high standards but even more to his personal qualities, which enlisted the co-operation of anyone who came into contact with him, and the devoted loyalty of all his colleagues, both senior and junior.

\section{Dr. Paul Haas}

Paul HaAs, who died on April 6 at Cheam, was born in 1877, the son of distinguished parents. His father was professor of Sanscrit at University College, London, and his mother was a gifted pianist who, before her marriage, had a European reputation as a soloist. Even in her old age, Madam Haas played the music of Bach in a manner few could equal, and her son inherited musical appreciation.

Paul Haas was educated at University College School when it was in Gower Street, then at University College, and he studied also both at Freiburg and Geneva. As an investigator, he was very deliberate and conscientious. With the late Prof. T. G. Hill, he collaborated in the investigation of the biochemistry of seaweeds and the chromogens of Mercurialis perennis, and they produced, in 1913, "An Introduction to the Chemistry of Plant Products", which was afterwards extended into a two-volume work.

It was in teaching, however, that Haas found his chief interests, and his lectures and demonstrations were always carefully prepared. He lectured on organic chemistry both at St. Mary's and St. Thomas's Hospital Medical Schools, and also at the Royal Botanic Gardens, Kew, until he became reader in plant chemistry at University College, of which he was a Fellow.

Paul Haas had a retiring kindly personality with a quiet sense of humour. He looked after his mother devotedly, at their home in Westbourne Park, until her death, and his colleagues had regarded him as a confirmed bachelor. But romance came to him when inspecting schools for the University of London, and at the age of sixty-one he married Beryl Grace Wood who, with a son of the marriage, survives him.
E. J. Salisbury 